\title{
NOTA/NOTE
}

\section{Chaetaster nodosus Perrier, primera estrella de mar perteneciente a la familia Chaetasteridae (Echinodermata: Asteroidea) registrada para el Caribe colombiano}

\section{Chaetaster nodosus Perrier, first starfish belonging to the family Chaetasteridae (Echinodermata: Asteroidea) registered for the Colombian Caribbean}

\author{
Laura Cristina Moreno-Jiménez ${ }^{1,2^{*}}$ y Giomar Helena Borrero-Pérez ${ }^{2}$ \\ (iD) $0000-0001-5559-4385 \quad$ (iD) $0000-0003-3091-3938$
}

1. Universidad EAFIT, Medellin, Colombia.lmoren16@eafit.edu.co*

2. Instituto de Investigaciones Marinas y Costeras “José Benito Vives de Andréis” (Invemar), Santa Marta, Colombia. giomar.borrero@invemar.org.co

* Autora de correspondencia.

\section{RESUMEN}

$\mathrm{E}$ ste trabajo registra por primera vez para el Caribe colombiano la familia monogenérica Chaetasteridae (Echinodermata: Asteroidea) con base en un ejemplar de la estrella de mar Chaetaster nodosus Perrier 1875 colectado frente a las islas de San Bernardo a $98 \mathrm{~m}$ de profundidad. Se incluye una breve descripción de la especie e información acerca de su distribución.

PALABRAS CLAVE: primer registro, Colombia, distribución geográfica, distribución batimétrica, descripción taxonómica

\section{ABSTRACT}

This work reports for the first time for the Colombian Caribbean the monogeneric family Chaetasteridae (Echinodermata: Asteroidea) based on a specimen of the starfish Chaetaster nodosus Perrier, 1875 collected off the San Bernardo islands at $98 \mathrm{~m}$ depth. A brief description of the species and information about its distribution is included.

KEY WORDS: first record, Colombia, geographic distribution, bathymetric distribution, taxonomic description 
Chaetasteridae es una familia de la clase Asteroidea (phylum Echinodermata) que incluye únicamente dos especies para el océano Atlántico, ambas en el género Chaetaster: Chaetaster nodosus Perrier y Chaetaster longipes (Bruzelius) en elAtlántico oriental(Clark y Downey, 1992). Esta clase, que agrupa las comúnmente conocidas estrellas de mar, es uno de los taxones más abundantes y diversos dentro del phylum Echinodermata (Pawson, 2007). En Colombia, el conocimiento sobre este grupo ha ido aumentando. Según Alvarado (2011) y Pérez-Ruzafa et al. (2013), Colombia es uno de los países de Latinoamérica con el mayor número de especies de asteroideos. Álvarez (1981) presentó un listado preliminar de los equinodermos del Caribe colombiano donde citó once especies del grupo; posteriormente, Benavides-Serrato et al. (2005) presentaron un listado taxonómico de los asteroideos de la plataforma y del talud superior del Caribe colombiano y en él citaron 35 especies. Finalmente, el trabajo más actualizado y completo para este grupo es el de Benavides-Serrato et al. (2011), en el cual mencionan 67 especies diferentes de asteroideos para el Caribe colombiano.

Un ejemplar perteneciente al género Chaetaster nodosus fue recolectado frente a las islas de San Bernardo, en Archipiélagos Coralinos. Esta es una de las ecorregiones definidas para el Caribe colombiano que está conformada por islas, plataformas de carbonato poco profundas y bancos de coral ubicados en la costa continental, entre las islas del Rosario e isla Fuerte, así como por contornos de la plataforma continental de entre 40 y $130 \mathrm{~m}$ de profundidad. Esta ecorregión de aguas claras posee una alta diversidad de especies, así como hábitats con arrecifes de coral, planicies de arena bioclásticas, lechos marinos y manglares en algunas de sus islas (Díaz y Acero, 2003).

El individuo recolectado fue separado y preservado en etanol al $70 \%$ y fotografiado e identificado utilizando las claves taxonómicas de Downey (1973) y Clark y Downey (1992). El ejemplar fue depositado en la colección de equinodermos del Museo de Historia Natural Marina de Colombia (MHNMC) Makuriwa del Instituto de Investigaciones Marinas y Costeras (Invemar).

\section{Phylum Echinodermata}

\section{Clase Asteroidea}

Familia Chaetasteridae Sladen, 1889

Género Chaetaster Müller y Troschel, 1840
Chaetasteridae is a family of the class Asteroidea (phylum Echinodermata) that includes only two species for the Atlantic Ocean, both belonging to the genus Chaetaster, which are Chaetaster nodosus Perrier, 1875 and Chaetaster longipes (Bruzelius, 1805) in the eastern Atlantic (Clark and Downey, 1992). This class, which includes the animals commonly known as starfishes, is one of the most abundant and diverse taxa in the phylum Echinodermata (Pawson, 2007). In Colombia, the knowledge about this group had been increasing. According to Alvarado (2011) and PérezRufaza et al. (2013), Colombia is one of the Latin-American countries with the largest number of asteroids species. Álvarez (1981) presented an initial list of echinoderms for the Colombian Caribbean, where he cited eleven asteroids species. Subsequently, Benavides-Serrato et al. (2005) presented a taxonomic list of the asteroids of the continental shelf and the upper slope of the Colombian Caribbean, in which they cited 35 species. Finally, the most actualized and complete paper (Benavides-Serrato et al., 2011) mentioned 67 species of asteroids for the Colombian Caribbean.

One specimen of Chaetaster nodosus was collected in Coralline Archipelagos, in front of San Bernardo islands. Coralline Archipelagos is one of the ecoregions defined for the Colombian Caribbean that is encompassed by islands, shallow carbonate platforms, and coral shoals located off the mainland coast between Islas del Rosario and Isla Fuerte, as well as the continental shelf between 40 and $130 \mathrm{~m}$ depth. This clear water ecoregion has a high diversity of species, as well as habitats with coral reefs, bioclastics sand flats, seagrass beds and mangroves in some islands (Díaz and Acero, 2003).

The collected specimen was separated and preserved in $70 \%$ ethanol, photographed and identified using the taxonomic keys presented by Downey (1973) y Clark y Downey (1992). The specimen was deposited in the echinoderm collection of the Marine Natural History Museum of Colombia (MHNMC) Makuriwa of the Marine and Coastal Research Institute (Invemar).

\section{Phylum Echinodermata}

\section{Class Asteroidea}

Family Chaetasteridae Sladen, 1889

Genus Chaetaster Müller y Troschel, 1840

Chaetaster nodosus Perrier, 1875 

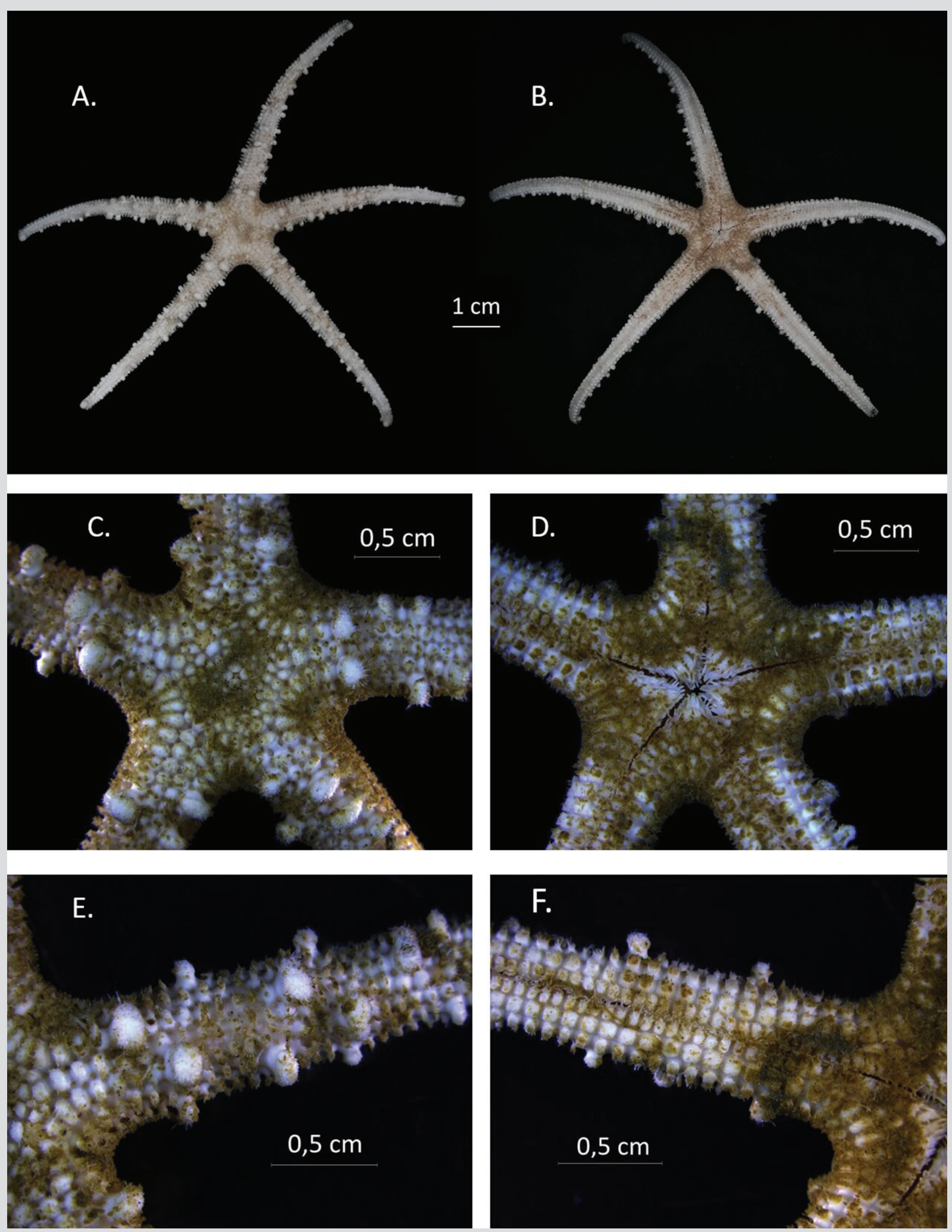

Figura 1. Chaetaster nodosus. A) Vista general abactinal. B) Vista general actinal. C) Acercamiento al disco en vista abactinal. D) Acercamiento al disco en vista actinal. Se detalla la mandíbula. E) Acercamiento a uno de los brazos en vista abactinal. Se observan las placas nodosas que sobresalen de la superficie general. F) Acercamiento a uno de los brazos en vista actinal. Se observa el surco ambulacral y las

Figure 1. Chaetaster nodosus. A) General abactinal view. B) General actinal view. C) Disc detail in abactinal view. D) Disc detail in actinal view showing the jaw. E) Arm detail in abactinal view. Nodoses plates raised above the general surface observed. F) Arm detail in actinal view. Ambulacral groove and the adambulacral plates observed. placas adambulacrales. 
Referencias de identificación: Downey (1973: 65, Pl. 24 C, D), Clark y Downey (1992: 144, 146, Pl. 35 C, D).

Material examinado: un ejemplar INV EQU4789, R: $50 \mathrm{~mm}$, r: 7 mm, R/r: 7,1/1, E 327 B $\left(9^{\circ} 37^{\prime} 04^{\prime \prime}\right.$ N-76 $\left.16^{\prime} 41^{\prime \prime} \mathrm{W}\right)$, $98 \mathrm{~m}$ de profundidad.

Descripción: disco pequeño con cinco brazos largos, estrechos y redondos, que disminuyen su grosor hasta terminar (Figura 1A). Placas abactinales bien espaciadas en filas regulares, una fila carinal y cuatro o cinco dorsolaterales en cada lado; solo una de las hileras continúa hasta la placa terminal; placas más o menos iguales en tamaño, aunque pueden ser un poco irregulares en cuanto a su forma (Figura 1C). Placas abactinales subpaxiliformes, con la parte superior ancha y plana densamente cubierta con pequeños tubérculos en forma de gránulos con espinas hialinas; algunas placas dispersas en los brazos grandes y elevadas por encima de la superficie general, claramente nodosas (Figura 1E); paxilas muy cerca, casi se tocan entre ellas, de modo que la base de la placa está oculta. Pápulas grandes e individuales ubicadas entre las placas. Dos series de placas marginales grandes y rectangulares en su mayoría confinadas a la superficie inferior, con la misma ornamentación de las placas abactinales, siendo las proximales mucho más anchas que largas. Pocas placas actinales, confinadas al disco. Placas adambulacrales con 6-7 espinas muy cortas y gruesas paralelas al surco y un parche subpaxilado de espinas subambulacrales similares a las abactinales y marginales. Placas bucales pequeñas, estrechas, densamente cubiertas con espinas largas afiladas (Figura 1D). Madreporita pequeña, plana y profundamente canalizada. Placa terminal grande, desnuda y redonda (Downey, 1973; Clark y Downey, 1992).

Distribución: Chaetaster nodosus se distribuye en el Atlántico oriental en las islas Canarias (Pérez-Ruzafa et al., 2013) y en el Atlántico occidental desde Bermuda y Carolina del Norte (Estados Unidos), incluyendo el golfo de México y el Caribe (Cuba, Venezuela, Surinam y Colombia), hasta Brasil (4 S) (Clark y Downey, 1992; GBIF.org, 2019; Orrel, 2019) (Figura 2). En este documento se registra la especie por primera vez para Colombia con base en el ejemplar recolectado en el proyecto ICP y, además, se incluye un individuo depositado en el Museo Nacional de Historia Natural del Smithsonian (NMNH-Smithsonian) con el número de catálogo USNM 1226493. Este ejemplar fue recolectado en el año 1965 por el R/V Oregon (Servicio de Pesca y Vida Silvestre de Estados Unidos) en el noroeste de la península de la Guajira a una profundidad de $207 \mathrm{~m}$. Esta
Identification references: Downey (1973: 65. Pl. 24 C, D), Clark and Downey (1992: 144, 146. Pl. 35 C, D).

Material examined: 1 specimen INV EQU4789, R: $50 \mathrm{~mm}$, r: 7 mm, R/r: 7.1/1, E 327 B (9³7'04" N-76 16'41" W), 98 m depth.

Description: Disc small with five long, slender, rounded arms, tapering to acute point (Figure 1A). Well-spaced abactinal plates in regular rows; one carinal row and four or five dorsolaterals on each side; only one row continuing all the way to the terminal plate; plates more or less equal in size, somewhat irregular in shape (Figure 1C). Abactinal plates subpaxillate, with broad flat top densely covered with small granule-like tubercles bearing hyaline spinelets; a few scattered plates on the arms larger, raised above the general surface, being distinctly nodose (Figure 1E); paxillae nearly touching, concealing the base of plates. Large single papulae between plates. Two series of large rectangular marginals plates mostly confined to lower surface, armed like abactinal plates, proximal ones much broader than long. Actinal plates few, confined to disc. Adambulacral plates bearing 6-7 very short, stubby furrow spines parallel to groove, and a subpaxillate patch of subambulacral spinelets similar to those of abactinal and marginals. Mouth plates small, narrow, densely covered with long sharp spines (Figure 1D). Madreporite small, flat, and deeply channeled. Terminal plate large, bare and round (Downey, 1973; Clark and Downey, 1992).

Distribution: Chaetaster nodosus is distributed in the eastern Atlantic in the Canary Islands (Pérez-Ruzafa et al., 2013) and in the western Atlantic from Bermuda and North Carolina (USA), including the Gulf of Mexico and the Caribbean (Cuba, Venezuela, Suriname and Colombia) to Brazil ( $\left.4^{\circ} \mathrm{S}\right)$ (Clark and Downey, 1992; GBIF.org, 2019; Orrel, 2019) (Figure 2). This paper reports the species for the first time in Colombia, based on one specimen collected in the ICP project. In addition, one individual deposited in the National Museum of Natural History from the Smithsonian (NMNHSmithsonian), catalog number USNM 1226493, is included. This individual was collected in 1965 by the United States Fish and Life Service, northwest of the Guajira peninsula at $207 \mathrm{~m}$ depth by the R/V Oregon. This depth would expand the bathymetric range of the species cited by Clark and Downey (1992) which is 53 to $207 \mathrm{~m}$.

Comments: Although currently Chaetasteridae is recognized as a family, Downey (1973) considered the genus Chaetaster a highly specialized ophidiasterid, 


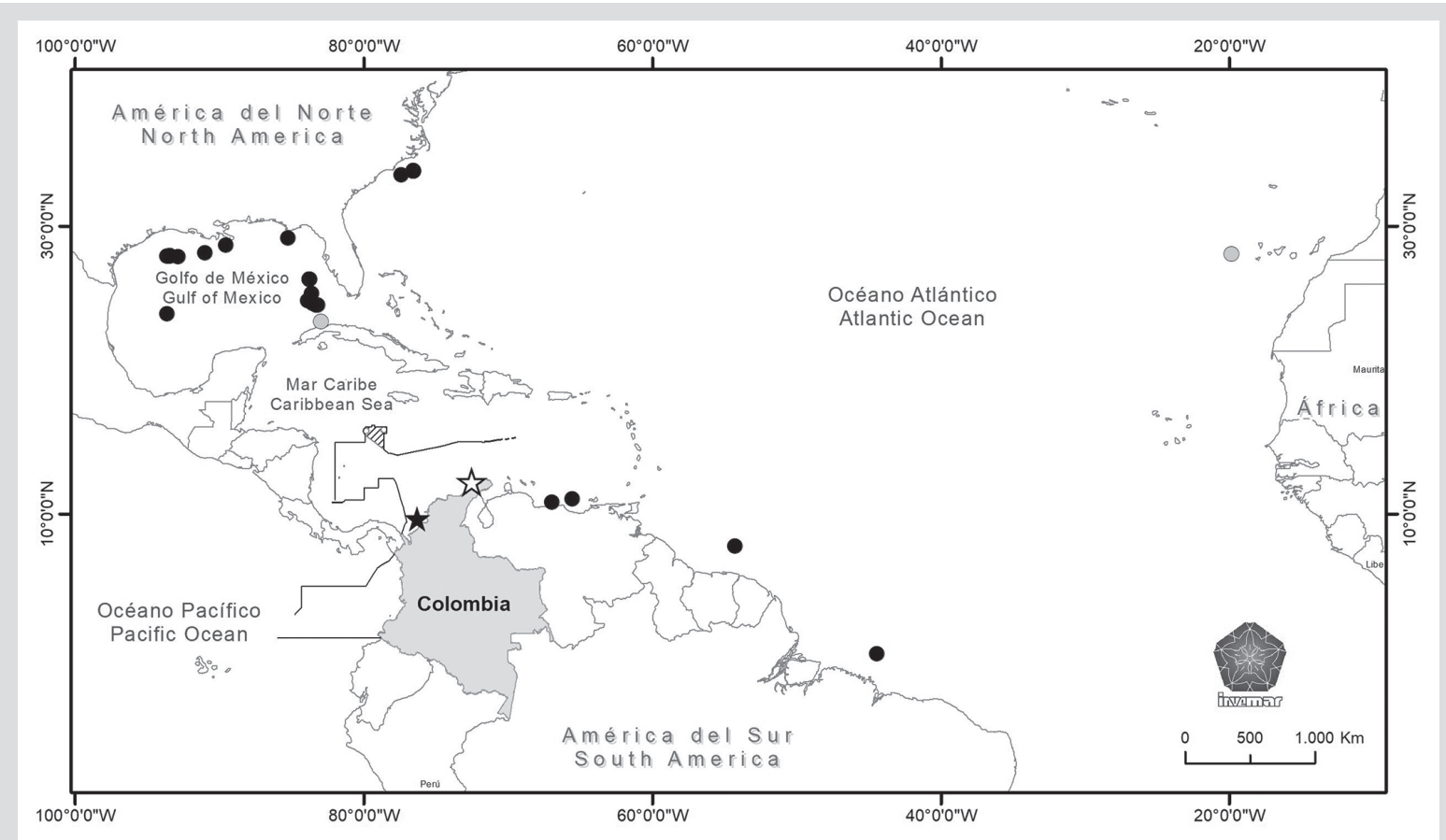

Figura 2. Distribución geográfica conocida de la especie Chaetaster nodosus. Se indica la localidad del ejemplar recolectado en el proyecto ICP (estrella negra) y la del ejemplar USNM 1226493 de Colombia (estrella blanca); los registros de la especie incluidos en las bases de datos del GBIF y del NMNH-Smithsonian (puntos negros), y los de Alvarado y Solís-Marín (2013), los cuales no corresponden a coordenadas exactas (puntos grises).
Figure 2. Known geographical distribution of the Chaetaster nodosus species. It indicates the location of the specimen collected in the ICP project (black star) and that of the specimen USNM 1226493 from Colombian (white star); the records of the species included in the GBIF and NMNH-Smithsonian databases (black dots), and those of Alvarado and Solís-Marín (2013), which do not correspond to exact coordinates (gray dots). profundidad amplía el intervalo de la especie registrado por Clark y Downey (1992), el cual va entonces de 53 a $207 \mathrm{~m}$.

Comentarios: aunque actualmente Chaetasteridae es una familia aceptada, Downey (1973) consideró el género Chaetaster como un ophidiastérido altamente especializado, con lo que abolió la familia Chaetasteridae y restauró este género dentro de la familia Ophidiasteridae, de la cual había sido removido anteriormente. Chaetasteridae también ha sido colocada en o cerca de Echinasteridae y Asterinidae. Por otro lado, Tommasi (1971) describió Chaetaster vanzolinicus diferenciándola de C. nodosus por una mayor cantidad de filas de placas abactinales (dorsales y laterales) en los brazos. Sin embargo, esa especie no fue aceptada, debido a que el número de filas de las placas no parecía ser mucho mayor y a que las filas adicionales que pudieran estar presentes se explicaron por el tamaño mayor del espécimen con respecto al promedio (el número de filas y el tamaño de las placas en muchas estrellas de mar aumenta con el crecimiento del organismo) (Clark, 1922; Clark y Downey, 1992). El ejemplar recolectado por el Invemar podría ser un juvenil considerando las tallas registradas por Clark y Downey (1992) de $\mathrm{R}=90 \mathrm{~mm}$ y $\mathrm{R} / \mathrm{r}=8,2 / 1$. synonymizing Chaetasteridae family and restoring this genus to the family Ophidiasteridae, from which it had been previously removed. Chaetasteridae has also been placed in or near Echinasteridae and Asterinidae. On the other hand, Tommasi (1971) described Chaetaster vanzolinicus as a species different from $C$. nodosus, because of the greater number of rows of abactinal plates (dorsal and lateral) on the arms. However, this species was not accepted, because the number of rows of plates does not seem to be much higher. Also, the additional rows that could be present were explained by the larger size of the specimen respects to the average, since the number of rows and the size of the plates in many starfish increase with growth (Clark, 1922; Clark and Downey, 1992). The specimen collected could be a juvenile considering the size reported by Clark and Downey (1992) of $\mathrm{R}=90 \mathrm{~mm}$ and $\mathrm{R} / \mathrm{r}=8.2 / 1$.

\section{ACKNOWLEDGMENTS}

The specimen of Chaetaster nodosus was collected during the project "Toxicidad de fluidos de exploración de hidrocarburos offshore en organismos nativos del Caribe 


\section{AGRADECIMIENTOS}

El material fue recolectado en el marco del proyecto "Toxicidad de fluidos de exploración de hidrocarburos offshore en organismos nativos del Caribe colombiano: ecosistemas profundos y sus recursos pesqueros en los bloques de exploración RC11, RC12, Fuerte Norte y Fuerte Sur, Caribe colombiano", proyecto ICP, desarrollado por el Invemar y Ecopetrol bajo el acuerdo de cooperación n. ${ }^{\circ} 1$ derivado del convenio n. ${ }^{\circ} 5211329$ del 2013. Se agradece a Manuel Garrido Linares y a Paola Flores Romero por la recolección y separación de los equinodermos durante este proyecto. Contribución 1274 del Invemar. colombiano: ecosistemas profundos y sus recursos pesqueros en los bloques de exploración RC11, RC12, Fuerte Norte y Fuerte Sur, Caribe colombiano", ICP Project, carried out by Invemar and Ecopetrol under Cooperation Agreement No. 01 derived from contract No. 5211329 of 2013 . Thanks to Manuel Garrido Linares and Paola Flores Romero for the collection and sorting of echinoderms during this project. Contribution 1274 of Invemar.

\section{BIBLIOGRAFÍA/LITERATURE CITED}

Alvarado, J.J. 2011. Echinoderm diversity in the Caribbean Sea. Mar. Biodiv., 41(2), 261-285. https://doi.org/10.1007/s12526-010-0053-0

Alvarado, J.J. and F.A. Solis-Marin. (Eds.). 2013. Echinoderm research and diversity in Latin America. Springer, Berlin. 658 p. https://doi.org/10.1007/9783-642-20051-9

Álvarez L., R. 1981. Listado preliminar de los equinodermos de la costa Atlántica colombiana. Bol. Mus. Mar., 10: 24-39.

Benavides-Serrato, M., G.H. Borrero-Pérez, Ó.D. Solano y G.R. Navas. 2005. Listado taxonómico de los asteroideos (Echinodermata: Asteroidea) de la plataforma y el talud superior del Caribe colombiano. Rev. Biol. Trop., 53(3): 171-194.

Benavides-Serrato, M., G.H. Borrero-Pérez y C.M. Díaz-Sánchez. 2011. Equinodermos del Caribe colombiano I: Crinoidea, Asteroidea y Ophiuoridea. Serie Publ. Espec. Invemar, (22). 384 p.

Clark, A.M. and M.E. Downey. 1992. Starfishes of the Atlantic. Chapman \& Hall, London. 168 p.

Clark, H.L. 1922. The echinoderms of the Challenger Bank, Bermuda. Proc. Am. Acad. Arts. Sci., 57(13), 353. https://doi.org/10.2307/20025925

Díaz, J.M. and A. Acero P. 2003. Marine biodiversity in Colombia: Achievements, status of knowledge, and challenges. Gayana (Concepción), 67(2): 261274. https://doi.org/10.4067/S0717-65382003000200011

Downey, M.E. 1973. Starfishes from the Caribbean and Gulf of Mexico. Smithson. Contr. Zool., 126. 168 p.

GBIF. 2019. GBIF occurrence download. https://doi.org/10.15468/d1.2sjiy0

Orrell, T. 2019. NMNH extant specimen records. Version 1.23. National Museum of Natural History, Smithsonian Institution. Occurrence dataset. https:// doi.org/10.15468/hnhrg3

Pawson, D. 2007. Phylum Echinodermata. Zootaxa, 1668: 749-764.

Pérez-Ruzafa, A., J.J. Alvarado, F.A. Solís-Marín, J.C. Hernández, A. Morata, C. Marcos, M. Abreu-Pérez, O. Aguilera, J. Alió, J.J. Bacallado-Aránega, E. Barraza, M. Benavides-Serrato, F. Benítez-Villalobos, L. Betancourt-Fernández, M. Borges, M. Brandt, M.I. Brogger, G.H. Borrero-Pérez, B.E. Buitrón-Sánchez, L.S. Campos, J.R. Cantera, S. Clemente, M. Cohen-Renjifo, S.E. Coppard, L.V. Costa-Lotufo, R. del Valle-García, M.E. Díaz de Vivar, J.P. Díaz-Martínez, Y. Díaz, A. Durán-González, L. Epherra, M. Escolar, V. Francisco, C.A. Freire, J.E. García-Arrarás, D.G. Gil, P. Guarderas, V.F. Hadel, A. Hearn, E.A. Hernández-Delgado, A. Herrera-Moreno, M.D. Herrero-Pérezrul, Y. Hooker, M.B.I. Honey-Escandón, C. Lodeiros, M. Luzuriaga, C.L.C. Manso, A. Martín, M.I. Martínez, S. Martínez, L. Moro-Abad, E. Mutschke, J.C. Navarro, R. Neira, N. Noriega, J.S. Palleiro-Nayar, A.F. Pérez, E. Prieto-Ríos, J. Reyes, R. Rodríguez-Barreras, T. Rubilar, T.I. Sancho-Mejías, C. Sangil, J.R.M.C. Silva, J.I. Sonnenholzner, C.R.R. Ventura, A. Tablado, Y. Tavares, C.G. Tiago, F. Tuya and S.M. Williams. 2013. Latin America echinoderm biodiversity and biogeography: patterns and affinities. 511-542. In: Alvarado, J.J. and F.A. Solis-Marin. (Eds.). Echinoderm research and diversity in Latin America. Springer, Berlin. 658 p. https://doi.org/10.1007/978-3-642-20051-9_16

Tommasi, L.R. 1971. Equinodermes do Brasil. I. Sôbre algumas espécies novas e outras pouco conhecidas, para o Brasil. Bol. Inst. Oceanogr., 20: 1-21. 